\title{
КАЗАНСКИЙ ПЕРИОД ЖИЗНИ И ДЕЯТЕЛЬНОСТИ ВОСТОКОВЕДА И.Н.БЕРЕЗИНА (ПО МАТЕРИАЛАМ ИЛЛЮСТРИРОВАННОЙ ЭНЦИКЛОПЕДИИ «КАЗАНЬ»)
}

\section{THE KAZAN PERIOD OF THE LIFE AND WORK OF THE ORIENTALIST I.N. BEREZIN (BASED ON THE MATERIALS OF THE ILLUSTRATED ENCYCLOPEDIA "KAZAN") \\ F. Kalimullina}

Summary: The paper examines the research and organizational activities of the famous Russian orientalist I.N. Berezin in the Kazan period of his life in 1834-1855. His works are analyzed in detail, and his contribution to the study of the history of Volga Bulgaria and the Golden Horde is revealed. It is emphasized that it was I.N. Berezin who was the first in Russian Oriental studies to so thoroughly study the tarkhan letters of the Golden Horde khans, and introduced new Turkic and Muslim sources into scientific circulation.

Keywords: Turkology, Oriental studies, Kazan Orientalism, history, I.N. Berezin, H. Faizkhanov, V.V. Velyaminov-Zernov, Eastern category of Kazan University, Eastern Faculty of Petersburg University, certificates of the Golden Horde khans, tarkhany certificates.
$\mathrm{T}$ юрколог, монголовед, иранист XIX в. Илья Николаевич Березин (1818-1896) занимает почетное место среди российских востоковедов. Его имя было широко известно не только в России, но и за ее пределами, как на Востоке, так и в Западной Европе. Ученый занимался не только исследованиями, но и преподаванием, организацией российской востоковедческой науки. Многогранная деятельность востоковеда требует более детального монографического исследования и, к сожалению, такой обобщающей работы в отечественной историографии в данный момент нет. Вклад ученого в отечественное востоковедение по достоинству не оценен и требует дальнейших исследований. В данной статье мы остановились на казанском периоде биографии И.Н. Березина, выявили направления и особенности его исследований. При этом его взгляды на отдельно взятые вопросы были сравнены с точкой зрения последующих ученых, что дало нам возможность определить заслуги И.Н. Березина в изучении тех или иных конкретных проблем тюркологии.

Жизнь и деятельность И.Н. Березина можно разделить на два этапа. Это казанский (1834-1855) и петербургский (1855-1896) периоды. Родом И.Н. Березин из Пермской губернии, сын горного чиновника. Учился в

\author{
Калимуллина Фирдаус Галимовна \\ к.и.н., в.н.С., Институт татарской энциклопедии и \\ регионоведения АН PT, (г. Казань) \\ kfirdaus@list.ru
}

Аннотация: В работе рассматривается научно-исследовательская и организаторская деятельность известного русского востоковеда И.Н. Березина в казанский период его жизни в 1834-1855 гг. Подробно анализируются его труды, выявляется вклад ученого в изучение истории Волжской Булгарии и Золотой Орды. Подчеркивается, что именно И.Н. Березин первым в российском востоковедении столь основательно изучил тарханные грамоты золотоордынских ханов, ввел в научный оборот новые тюркские, мусульманские источники.

Ключевые слова: тюркология, востоковедение, казанская ориенталистика, история, И.Н. Березин, Х. Фаизханов, В.В. Вельяминов-Зернов, Восточный разряд Казанского университета, Восточный факультет Петербургского университета, грамоты золотоордынских ханов, тарханные грамоты.

Екатеринбургском уездном училище и в Пермской гимназии. В 1834 г. поступил на восточный факультет Казанского университета, в котором пристально изучал арабский и персидский языки. Занятия проходили под руководством известного профессора Ф.Х. Эрдмана.

После окончания обучения, в 1837 г. И.Н. Березин был оставлен на работу в Казанском университете. Для получения профессорского звания ученый совершил научно-исследовательскую командировку в Астрахань. Изучал быт и обычаи мусульманских, тюркских народов. После возвращения из командировки И.Н. Березин защитил диссертацию под названием «Что способствует развитию просвещения и останавливает ход его в державах магометанских». В 1841 г. исследователю была присвоена степень магистра восточной словесности.

В 1842 г. по предложению профессора Мирзы КаземБека Казанский университет направил И.Н. Березина в трехлетнюю командировку на Восток - в Закавказье, Персию, Аравию, Египет и Турцию. Наряду с практикой и изучением языков, ученый собирал археографические материалы, предметы древности [1, с.7].

После командировки по восточным странам, ори- 
енталист снова приехал в Казань и в 1846 г. занял профессорскую кафедру турецкого языка, читал основные курсы турецко-татарского языка, «джагатайско-тюркской литературы», истории тюрок. Наряду с преподавательской деятельностью, И.Н. Березин изучал историю татарской государственности, обследовал останки города Булгар. Ученый также заинтересовался историей Золотой Орды [2].

За публикации в центральных периодических изданиях, в которых рассказывалось о результатах командировок в восточные страны, И.Н. Березин был избран членом Императорского Русского географического общества в Санкт-Петербурге [3, с. 1-7]. Следует отметить, что деятельность И.Н. Березина в научных обществах мало изучена и требует более детального исследования.

В казанский период жизни И.Н. Березина увидели свет его учебники по грамматике турецкого (1847 г.) и персидского (1853 г.) языков. В 1849-1854 гг. ученый издал трехтомную серию «Библиотека восточных турков», в 1850-1851 гг. им была опубликована двухтомная серия под названием «Библиотека восточных историков». Здесь ученый анализировал источники «Шейбани Наме» и «Джами-эт-Таварих» [4]. Он также в своих исследованиях остановился на вопросе изучения средневекового «Джагатайского словаря» к произведениям А. Навои [5].

И.Н. Березин в казанский период жизни заинтересовался историей Волжской Булгарии и в 1863 г. издал весомую монографию «Булгар на Волге». Объясняя причину, побудившую его к исследованию истории Волжской Булгарии, отметил следующее: «В древности Россия населена была различными народами, в том числе которых находились многие тюркские племена, большей частью исчезнувшие в кровопролитных войнах и политических переменах, слившиеся с победителями так, что не осталось и следа их существования, хотя некоторые из этих племен могли гордиться известной степенью образованности. В этом отношении, к числу самых замечательнейших принадлежит Булгарское государство на берегах Волги. Судьба этого царства, когда-то состоявшего в близких торговых отношениях с руссами, должна необходимо найти себе место в древней истории России... Народ булгарский не примкнут определенным образом ни к одному из известных племен. Разрешение этих любопытных недоумений история ожидает от филологии и археологии» [6, с. 1].

И.Н. Березин определил, что в годы процветания в Булгарах проживало до 50 тыс. населения. Ученый отметил влияние арабов в культуру и архитектуру Волжских Булгар. Если до принятия ислама строения были деревянными, то после принятия арабские архитекторы начали строить каменные мечети, крепости. Город Булгар построен по тому же способу, по которому строится весь мусульманский Восток: по краям стен наблюдается кладка больших необделанных камней с известью, а середина наполнена известью с мелкими камнями, - писал ученый [6, с. 15].

И.Н. Березиным подробно были описаны уцелевшие здания в Булгарах, при этом был подчеркнут именно арабский стиль в архитектуре. В большинстве случаев от зданий остались только фундаменты, «потому что материал дворцов более соблазнял позднейших строителей» [6, с. 26], - отмечал востоковед, сетуя на разрушения ценных исторических памятников. Он напомнил, что один из булгарских мавзолеев (тюрбе) позднее был переделан в церковь Святого Николая, по этой причине в фундаменте церкви имелись мусульманские надписи, а в церковном дворе находились мусульманские надгробия [6, с. 52].

И.Н. Березин обратил особое внимание на международные торговые связи Волжской Булгарии с государствами Восточной Европы. По его словам, на это указывали руины т.н. «Греческой палаты». Греческая палата являлась христианским сооружением, которая напоминала по типу строения армянские поминальные храмы. Это, скорее всего жилище и складочное место для ценных товаров какого-нибудь иностранного купца, постоянного жителя Булгар, - размышлял ученый [6, с. 26]. Он подробно описал христианские захоронения рядом с Греческой палатой. Следует отметить, что христианские захоронения в Булгарах более подробно были обследованы археологами лишь в начале XX в., исходя из этого, И.Н. Березина можно назвать первым исследователем христианских исторических памятников Булгар.

Описывая надписи на эпитафиях, И.Н. Березин обратил внимание на то, что и в булгарских, и в казанских надгробиях использовалась особая форма указания даты - словосочетание «джиати джур», что в переводе с арабского означало «пришествие угнетения». Исходя из перевода, он придал написанному смысл особой эры, вывел из числового значения букв 623 г. по хиджре, 1226 г. по христианскому летоисчислению. Учитывая тот факт, что это был период монгольских завоеваний, ученый сделал вывод, что Булгар был покорен в 1226 г. [6, c. 61]. На это словосочетание также обратил внимание востоковед В.В. Вельяминов-Зернов во время изучения мавзолея Хусейн-бека, памятника XIV в., расположенного близь Уфы. В.В. Вельяминов-Зернов затруднялся ответить, что означало словосочетание «джиати джур», но интуитивно отнес его лишь к дате, написанной словами, не акцентируясь на переводе [2, с. 79]. Ясность к данной проблеме внес татарский ученый Х. Фаизханов, отметивший, что «джиат джур» это - «йите йуз» (по тюрко-татарски - семьсот). У татар принято начальное «й» произносить и писать как «ж», - отмечал татарский ученый, указывая на ошибочность трактовки И.Н. Березина [7]. 
И.Н. Березин в своей книге подробно остановился также на вопросе принятия ислама в Волжской Булгарии. Для этого он анализировал источник «Таварихе Булгария» Хисамутдина Муслими [6, с.72]. Нужно отметить, что И.Н. Березин одним из первых ввел в научный оборот данный источник. Роль И.Н. Березина в изучении истории Волжской Булгарии ценна тем, что многие вопросы по проблеме впервые были подняты именно в его труде.

Как мы уже отмечали выше, другим направлением исследований И.Н. Березина являлась история Золотой Орды. В 1850 г. ученым был опубликован весомый труд о внутреннем устройстве данного государства. В первую очередь, он подчеркнул историческую взаимосвязь Золотой Орды и Древнерусского государства. И.Н. Березин изучил этимологию топонимов русских городов. Многие из них произошли от словосочетания «Сары Урда» - «Золотая Орда». Названия таких городов как Царев, Царевка, Царицын, Саратов в основе имеют слово «сары» («золотая»), предположил ученый [8, с.3].

Основными источниками труда И.Н. Березина послужили тарханные ярлыки золотоордынских ханов, пожалованных своим подданным. Ученый изучил тарханные грамоты Тимур Кутлуга, Тохтамыша и Саадет Гирея. Год спустя по данным ярлыкам ученый опубликовал еще один труд [8]. И.Н. Березин проанализировал ярлыки трех ханов, сравнивая их и определяя общие тенденции. Он также рассмотрел вопрос преемственности титула тарханства в Русском государстве. По его мнению, в России тарханная льгота стала уничтожаться с 1559 г., временно была приостановлена в 1672 г. Алексеем Михайловичем, окончательно отменена уже Петром I [8, с.6].

После И.Н. Березина вопросом тарханства занимался В.В. Вельяминов-Зернов. В.В. Вельяминову-Зернову удалось расширить круг лиц, которым в России давалась данная льгота. Было отмечено, что тарханство получали от государей также башкирские подданные Уфимского уезда [10, с.26-48]. В.В. Вельяминов-Зернов обнаружил источники, в которых упоминался факт выдачи тарханных грамот в конце XVIII в., что противоречило утверждениям И.Н. Березина об уничтожении тарханных льгот в начале XVIII В. В.В. Вельяминов-Зернов также выявил несколько видов тарханства в противовес утверждению И.Н. Березина о том, что все грамоты были одинакового достоинства [2, с. 80]. В своих трудах И.Н. Березин отмечал, что им могут быть допущены неточности в работе, так как тема исследуется впервые [8, с. 8]. Ученый составил подробную таблицу ордынских чинов, выделил сословия и установил формы податей, в этом отношении его работа имеет большую ценность.

После И.Н. Березина В.В. Радлов, В.В. Вельяминова-Зернов и А.Н. Самойлович занимались изучением ханских ярлыков и тарханных грамот [11]. Разработки А.Н. Курата, В. Котвича, А.К. Боровкова, А.П. Григорьева и других исследователей также обогатили материал по данной проблеме [12]. В 1979 г. историком М.А. Усмановым был опубликован весомый труд, в котором впервые был представлен 61 тюркский оригинал актов Золотой Орды (до этого было известно всего 8 документов) [13].

Перу И.Н. Березина принадлежит также труд о монгольских завоеваниях [14]. Здесь он опирался на сочинение персидского государственного деятеля и историка XII - начала XIV вв. Рашид ад-Дина «История монголов». Позднее данный источник был издан ученым отдельно [15].

В 1849-1855 гг. И.Н. Березин заведовал минцкабинетом в Казанском университете, в 1850-1855 гг. являлся цензором по изданию восточных книг, в 18521853 гг. - редактором неофициальной части «Казанских губернских ведомостей». После многолетней плодотворный работы в Казани, в 1855 г. И.Н. Березин переехал в Санкт-Петербург. Это было связано с тем, что с 1855 г. восточное отделение Казанского университета было перенесено в Петербург. В Петербургском университете в 1854 г. был создан восточный факультет, который сыграл важнейшую роль в развитии востоковедения России. Предпринятые меры при создании данного факультета, к сожалению, принесли урон другим центрам изучения Востока. В университетах Казани и Одессы прекратилось преподавание восточных языков, лучшие специалисты были переведены в Петербург. По этому поводу ученые придерживались разных мнений. Исполнявший после переезда обязанности декана восточного факультета Петербургского университета И.Н. Березин, почему-то, сразу же поддержал идею: «Перенесение будет легким, успешным и полезным», - отмечал ученый [16, с. 282]. Благодаря аргументам таких востоковедов, как В.Р. Розен, В.В. Вельяминов-Зернов, в историко-филологическом факультете Казанского университета снова были открыты две кафедры восточных языков - угро-финских и тюркских наречий $[17$, с. 9]. Почему И.Н. Березин легко поддержал перенесение, губительное для востоковедения Казанского университета, в котором он состоялся как ученый, неизвестно. Скорее всего, он увлекся больше управленческими, административными обязанностями, нежели размышлениями о вреде или пользе переноca.

В петербургский период жизни И.Н. Березин защитил докторскую диссертацию о Золотой Орде и заинтересовался энциклопедическим жанром. В 1872-1879 гг. он издавал «Русский Энциклопедический словарь» (в 16 томах), в 1888-1884 г. выпустил «Новый энциклопедический словарь» (в двух томах). Здесь следует отметить, что его вклад в российскую энциклопедистку требует отдельного изучения. 
Подводя итоги, отметим, что в казанский период жизни И.Н. Березин написал ряд научных трудов, имеющий огромное значение в российском востоковедении. Изданные им учебники - грамматика турецкого и персидского языков долгое время являлись учебным пособием для востоковедов. Ученый после себя оставил весомое научное наследие, имеющее актуальность и в современ- ной науке. Он одним из первых изучил историю Волжской Булгарии, Золотой Орды, ввел в научный оборот такие ценные средневековые исторические источники «Шейбани Наме», «Джами-эт-Таварих», «Историю монголов» Рашид ад-Дина, золотоордынские ханские ярлыки. Его научно-исследовательская деятельность не до конца изучена и ждет отдельного внимания.

1. Валеев Р.М. Илья Николаевич Березин, 1818-1896. - Казань, 2003. - 17 с.

\section{ЛИТЕРАТУРА}

2. Калимуллина Ф.Г. Вклад И.Н. Березина в российское востоковедение // Актуальные проблемы отечественной и зарубежной истории, филологии (взгляд молодых ученых и аспирантов). Сборник статей научно-практической конференции» (г. Казань, ОП «ИТЭР АН РТ», 22 апреля 2015 г.). - Казань, 2015. - С. 78-83.

3. Семенов П.П. История полувековой деятельности Императорского русского географического общества. 1845-1895. - СПб., 1896. - Ч. 1. - 510 с.

4. Валеева Ю.Н. Исторические труды профессора Ю.Н. Березина (казанский период) // Приволжский научный вестник. - № 2 (42). - 2015. - С.28-30.

5. Березин И.Н. Описание турецко-татарских рукописей, хранящихся в библиотеках Санкт-Петербурга. - СПб., 1847. - 24 с.

6. Березин И.Н. Булгар на Волге. - Казань, 1853. - 91 с.

7. Фейз-Ханов Хусейн. Три надгробных булгарских надписи (с тремя таблицами снимков) // Известия Императорского археологического общества. - СПб., 1863. - T. 4. - C. 395-404.

8. Березин И.Н. Внутреннее устройство Золотой Орды по ханским ярлыкам. - СПб., 1850. - 24 с.

9. Березин И.Н. Тарханные ярлыки Тохтамыша, Тимур-Кутлука и Саадет-Гирея. - Казань, 1851. - 56 с.

10. Вельяминов-Зернов В.В. Источники для изучения тарханства, жалованного башкирам русскими государями. - СПб., $1864 .-50$ с.

11. Радлов В.В. Ярлыки Токтамыша и Темир-Кутлуга // Записки Восточного отделения Русского археологического общества. - СПб., 1899. -Т.3, вып. 1-2. - С.1-40; Самойлович А.Н. Несколько поправок к изданию и переводу ярлыков Тохтамыш-хана // Известия Таврического общества истории, археологии и этнографии. - Симферополь, 1927. - Т. 1. - С.141-144; Его же. Несколько поправок к ярлыку Тимур-Кутлуга// Известия Академии наук. СПб., 1918. - № 11. - С.1109-1124.

12. Котвич В.Л. Поправки к разбору монгольских писем персидских ильханов // Записки Коллегии востоковедов при Азиатском музее АН СССР. - Л., 1925. - Т. 1. - С.342-344; Боровков А.К. Опыт филологического анализа тарханных ярлыков, выданных ханами Золотой Орды русским митрополитам // Известия Академии наук СССР. - Т.25, - вып.1, 1966. - С.13-24; Григорьев А.П. Монгольская дипломатика. - Л., 1978. - 140 с.

13. Усманов М.А. Жалованные акты Джучиева Улуса XIV-XVI вВ. -Казань, 1979. - 428 с.

14. Березин И.Н. Первое нашествие монголов на Россию. - СПб., 1853. -30 с.

15. Березин И.Н. Сборник летописей «История монголов». Сочинение Рашид-Эддина. - СПб, 1858. - 322 с.

16. Материалы для истории факультета восточных языков. 1865-1901. -СПб., 1906. - Т. 2. - 339 с.

17. Бартольд В.В. Сочинения по истории востоковедения. - М., 1977. - Т. 9. - 969 С. 